\title{
Rape as a Continuing Weapon of Psychological Warfare, Suppression \& Subjugation
}

\author{
Mr. Aniruddha Vithal Babar ${ }^{1 *}$
}

\section{ABSTRACT}

"Beyond the daily gun battles, women have been a powerful voice in the opposition in villages and towns across Syria. In response, the Syrian government is punishing women for delivering humanitarian assistance, participating in protests, and supporting the opposition by subjecting them to detention, torture, and sexual assault."

\section{- Liesl Gerntholtz, women's rights director}

Rape and sexual abuse is not just a by-product of war but has been used as a deliberate warfare strategy from time to time. The opportunistic rape and pillage of previous centuries has been replaced by rape used as a strategic combat tool. Women and girls are particularly targeted by the use of sexual violence, including as a tactic of war to humiliate, dominate, instill fear in, disperse and/or forcibly relocate civilian members of a community or ethnic group. This paper examines historical and contemporary instances wherein sexual violence, specifically rape, was used as a strategic weapon of psychological warfare in various types of conflicts. It further analyzes the cogency of sexual violence as a weapon by considering its physical and psychological effects on victims and the morale of targeted populations. Additionally, it scrutinizes the motivations and intentions that support the use of sexual violence. The intent of this paper is to identify the use of rape from psychological perspective in socio-political spectrums of different types of conflicts. This paper thus offers multidimensional psycho-sociopolitical analysis of sexual violence in general and rape in particular as a major weapon of war.

Keywords: Rape, Psychological Warfare, Violence, Women

\section{INTRODUCTION-THE SOCIAL DYNAMICS OF RAPE}

" $\boldsymbol{R}$ ape is loss. Like death, it is best treated with a period of mourning and grief. We should develop social ceremonies for rape, rituals that, like funerals and wakes, would allow the mourners to recover the spirits that the rapist, like death, steals. The social community is the

\footnotetext{
${ }^{1}$ Assistant Professor, Seedling School of Law \& Governance, Jaipur National University, Jaipur

*Responding Author

(c) 2016 I A Babar; licensee IJIP. This is an Open Access Research distributed under the terms of the Creative Commons Attribution License (http://creativecommons.org/licenses/by/2.0), which permits unrestricted use, distribution, and reproduction in any Medium, provided the original work is properly cited.
} 
appropriate center for the restoration of spirit, but the rape victim is usually shamed into silence or self-imposed isolation."

Metzger (American Journal of Psychiatry, 1976)

Sex is understood as the biological difference between men and women. Even though this difference should not matter to how people are seen and treated, the distinction between both is assigned through by gender and does make a difference ${ }^{\mathrm{i}}$. Gender violence is a term for wide range of violations, which consist of both the physical and the sexual, from example ranging from sexual assault in society to sexual abuse in prison. Women are disproportionately the victims of gender violence, which happens in different forms in different social contexts throughout the world ${ }^{\mathrm{ii}}$. Rape is the most underreported crime in India. Rape is a type of sexual assault usually involving sexual intercourse or other forms of sexual penetration perpetrated against a person without that person's consent. The act may be carried out by physical force, coercion, abuse of authority or against a person who is incapable of giving valid consent, such as one who is unconscious, incapacitated, has an intellectual disability or below the legal age of consent. ${ }^{\text {iii }}$ The term rape originates in the Latin rapere (supine stem raptum), "to snatch, to grab, to carry off". ${ }^{\text {iv }}$ Since the 14 th century, the term has come to mean "to seize and take away by force". ${ }^{v}$ In Roman law the carrying off of a woman by force, with or without intercourse, constituted "raptus". ${ }^{\text {in }}$ In Medieval English law the same term could refer to either kidnapping or rape in the modern sense of "sexual violation". ${ }^{\text {vii }}$ The original meaning of "carry off by force" is still found in some phrases, such as "rape and pillage" or in titles, such as the story of the Rape of the Sabine Women or the poem The Rape of the Lock, which is about the theft of a lock of hair.

The Democratic Republic of the Congo (DRC) is accurately referred to as "the rape capital of the world". viii John Holmes, the under secretary general for humanitarian affairs for the United Nations has been reported saying, "the sexual violence in Congo is the worst in the world. The sheer numbers, the wholesale brutality, the culture of impunity - it's appalling”. ${ }^{\text {ix } W i t h ~ m o r e ~ t h a n ~}$ five million dead, tens of thousands of women raped all within the past decade, doctors and activists have called it an "epidemic.” Michael Van Rooyen, director of Harvard's Humanitarian Initiative, has had experience in international disaster zones. He says, "even in a wartime setting, Congo is unusual and exceptional." Such a reality is frightening and difficult to imagine, yet it is a reality many Congolese women have faced. This large-scale magnitude of sexual violence has potentially made eastern Congo the worst place on earth for a woman. If one take a case study of Cango Rape Victims, one can understand that the multidimensional reality of Rape. It was not only lust that prevailed, but something else as well, that is -The assertion of power.

The case of India is no different. The sexual violence has long been used as a tool of suppression and subjugation apart from uncivilized, immoral way to the forceful satisfaction of sexual urge. India, a nation which had Mahatma Gandhi as its role model of rectitude became so unbelievably violent and corrupt that the women can no longer be safe within their bodies. Gandhi who defeated the whites to save the browns by relying on non-violence is considered as the father of 


\section{Rape as a Continuing Weapon of Psychological Warfare, Suppression \& Subjugation}

the nation, but his values are being betrayed so easily that a woman is raped every twenty minutes ${ }^{\mathrm{x}}$ in the world's largest democracy and even children of five years are subjected to rape. ${ }^{\mathrm{xi}}$ According to the National Crime Records Bureau 2013 annual report, 24,923 rape cases were reported across India in $2012^{x i i}$. Out of these, 24,470 were committed by someone known to the victim (98\% of the cases). ${ }^{\text {xiii }}$ According to 2012 statistics, New Delhi has the highest raw number of rape reports among Indian cities. ${ }^{\text {xiv }}$ India has been characterised as one of the "countries with the lowest per capita rates of rape". ${ }^{\mathrm{xv}}$ The National Crime Records Bureau of India suggests a reported rape rate of 2 per 100,000 people, much lower than reported rape incidence rate statistics for many nations tracked by the United Nations. ${ }^{\text {xvi }}$

The sexual violence against women in India has an angle of "social status" apart from biological sex and sociological gender. Dalit women suffer from severe limitations in access to justice and there is widespread impunity in cases where the perpetrator is a member of a dominant caste, above the Dalits in the caste system. Dalit women are therefore considered easy targets for sexual violence and other crimes, because the perpetrators almost always get away with it. For example, in India, studies show that the conviction rate for rapes against Dalit women is under $2 \%$ compared to a conviction rate of $25 \%$ in rape cases against all women in India. The 2009 report of the UN Special Rapporteur on Violence against Women contains an overwhelming number of accounts of Dalit women in India being raped and beaten by higher castes in the course of their daily lives, such as while working in the field, going to the market or doing domestic work. ${ }^{\text {xvii }}$ Certain kinds of violence are traditionally reserved for Dalit women: extreme filthy verbal abuse and sexual epithets, naked parading, dismemberment, being forced to drink urine and eat faeces, branding, pulling out of teeth, tongue and nails, and violence including murder after proclaiming witchcraft, are only experienced by Dalit women. Dalit women are threatened by rape as part of collective violence by the higher castes. The Devadasi system of temple prostitution is the most extreme form of exploitation of Dalit women. Dalit girl children are forced to prostitution. The majority of cases of violence against Dalit women are not registered. The lack of law enforcement leaves many Dalit women unable to approach the legal system to seek redress. Women are often also unaware of the laws and their ignorance is exploited by their opponents, by the police, and by the judiciary system. Even when cases are registered, the lack of appropriate investigation, or the judge's own caste and gender biases, can lead to acquittal. ${ }^{\text {xiii }}$ Considering the social dynamics of Indian society one can conclude that though the degree of collective sexual violence against women is similar irrespective of their caste and social status however, the social dynamics and motives that forms the basis of violence significantly differs.

Incidents of Rapes committed by Police, Paramilitary and Armed Forces of Nation compel us to look at Rape from different angle. Many incidents of Rape have come up from time to time wherein defense personnel were involved. In 1991, the 4 Rajputana Rifles unit are alleged to have entered the village of Kunan Poshpora in Jammu \& Kashmir and raped between 30 and 100 women aged between 13 and 70. ${ }^{\text {xix }}$ In one well-publicized case, in May 1990 a young bride, Mubina Gani, was detained and raped by BSF soldiers while she was traveling from the wedding 
to her husband's home. Her aunt was also raped. The security forces had also fired on the party, killing one man and wounding several others. The government claimed that the party had been caught in "cross-fire." After the incident was publicized in the local and international press, Indian authorities ordered the police to conduct an inquiry. Although the inquiry concluded that the women had been raped, the security forces were never prosecuted. ${ }^{\mathrm{xx}}$ The rapes by Islamic militants have been reported since the Indo-Pakistani War of 1947. On 22 October 1947, Pashtun militants invaded Baramulla in a Pakistan army truck, and raped women including European nuns. ${ }^{x x i}$ During the 1971 Bangladesh war for independence, members of the Pakistani military and supporting Bihari and Razakar militias raped between two and four hundred thousand Bangladeshi women in a systematic campaign of genocidal rape. ${ }^{\text {xxii }}$ The writer Mulk Raj Anand said of the inhuman Pakistani army actions in 71' War, "The rapes were so systematic and pervasive that they had to be conscious Army policy, "planned by the West Pakistanis in a deliberate effort to create a new race" or to dilute Bengali nationalism". In March 1990, Mrs. M. N. Paul, the wife of a BSF inspector was kidnapped, tortured and gang-raped for many days. Then her body with broken limbs was abandoned on a road ${ }^{\text {xxiv }}$. Extremist and Terrorist organisations such as Hizb-ul-Mujahideen, Jamiat-ul-Mujahideen and Harkat ul-Ansar have been accused of carrying out rapes. ${ }^{\mathrm{xxv}}$ The Jammu Kashmir Liberation Front have been accused of ethnic cleansing by using murder, arson and rape as a weapon of war to drive out hundreds of thousands of Hindu Kashmiri Pandits from the region ${ }^{\text {xxvi }}$. Human rights groups allege that the Indian armed forces under the protection of the Armed Forces (Special Powers) Act, 1958 have carried out a large amount of rapes in the Nagaland, Assam and Manipur provinces. In recent years, varieties of rapes have taken place during the communal riots. During the post 2002 Godhra train burning, in the certain parts of Gujarat, rape was carried out by rioters.

Thirteen rape and assault cases were reported during the 2013 Muzaffarnagar riots. ${ }^{\text {xxix }}$ The different incidents of sexual violence cited herein above not only give a picture of human brutality but also shows us how alleged sexual violence was systematically used to as a psychological weapon of full-fledged war and civil armed conflicts to suppress and subjugate the target population. Hence, the subject of sexual violence should necessarily be studied in the light of three angles viz; Gender, Social Status and political-military strategic needs (War tactics).

\section{HISTORY OF RAPE AS A STRATEGIC WEAPON OF WAR}

Women's lives and their bodies have been the unacknowledged casualties of war for too long.

Amnesty's 'Lives Blown Apart' report

Specifically, rape and sexual torture are frequently used as weapons to demoralize the enemy; women are sometimes forced into "temporary marriages" with enemy soldiers. Women who are incarcerated may be subjected to sexual violence by prison guards and police officers. Other forms of sexual violence include, but are not limited to: 
1. Sexual slavery

2. Sexual harassment (including demands for sex in exchange for job promotion or advancement or higher school marks or grades)

3. Trafficking for the purpose of sexual exploitation

4. Forced exposure to pornography

5. Forced pregnancy

6. Forced sterilization

7. Forced abortion

8. Forced marriage

9. Female genital mutilation

10. Virginity tests

11. Incest

However, In order to understand the genesis of Wartime Sexual Violence including Rape it is pertinent to take a look in the chambers of history throughout which, rape during war has been commonplace, even encouraged. Homer's Iliad ${ }^{\mathrm{xxx}}$ opens with an argument between the Greek warriors Agamemnon and Achilles over possession of women seized during the Trojan War. In Biblical times, warriors also considered women spoils of war; they treated women as livestock, children, and other property in a conquered city. Biblical law told warriors that they "may take these as plunder ... and you may use the plunder the Lord your God gives you from your enemies." The rights of women during war apparently had made some progress since Homer's day, however; according to Biblical law, captive women who were physically attractive had to be wed before they could be raped. In ancient times, the law did not condemn rape and pillage if such actions were necessary as "a spur to the courage of troops." The winning side long ago discovered that rape was an effective battle strategy in the male-dominated world of war: 'Men of a conquered nation traditionally view the rape of "their women" as the ultimate humiliation, a sexual coup de grace. . . . Rape by a conquering soldier destroys all remaining illusions of power and property for men of the defeated side. The body of a raped woman becomes a ceremonial battlefield, a parade ground for the victor's trooping of the colors. The act that is played out upon her is a message passed between men-vivid proof of victory for one and loss and defeat for the other.' As one observer phrased this philosophy: "When I rape your woman, . . . I destroy your property. I insult you. I humiliate you. If I rape all your women, I defile an entire generation. And if I force your women to bear my children, I pollute your race." ${ }^{\text {xxxi }}$

Rape has always been a weapon of war which can also be recognized as genocide and/or ethnic cleansing when committed with the intent to destroy, in whole or in part, a targeted group; however, rape remains widespread in conflict zones. The 1994 UN Declaration on the Elimination of Violence against Women (DEVAW) also recognized women in conflict settings as an especially vulnerable group, and it encompassed Gender Based sexual Violence in its definition of violence against women provided in Article 2. The Declaration defines violence against women as "any act of gender-based violence that results in, or is likely to result in, 
physical, sexual or psychological harm or suffering to women, including threats of such acts, coercion or arbitrary deprivation of liberty, whether occurring in public or in private life,"xxxii which should be understood as including "physical, sexual and psychological violence perpetrated or condoned by the State, wherever it occurs." "xxxiii There are other international legal instruments to prosecute perpetrators but this has occurred as late as the 1990s. However, until recently it was neglected as a crime worthy of prosecution on its own. In the twentieth century, the use of rape in war was documented in both WWI and WWII. The practice continued during the Vietnam War and in civil war between Pakistan and Bangladesh during the 1970's. Rape as a weapon of war continues today. The rape of women and girls has been a brutal part of recent conflicts in Bosnia-Herzegovina, the Democratic Republic of Congo, Rwanda and Sudan and in too many other regions. The brutality took place despite the development and ratification of wide range international human rights instruments designed to address such degrading treatment both during peace time and in times of war. The trials at Nuremberg following WWII documented the use of rape as a weapon of war during that conflict. For example, the record described the German invasion of Russia this way: "Women and young girls are vilely outraged in all the occupied areas. In the Ukrainian village of Borodayevka, in the Dniepropetrovsk region, the fascists violated every one of the women and girls. In the village of Berezovka, in the region of Smolensk, drunken German soldiers assaulted and carried off all the women and girls between 16 and 30." ${ }^{\mathrm{xxxv}}$ It has also come to light that during WWII the Japanese army established front line brothels to service the Japanese Imperial Army. These 80,000-200,000 Asian women were sex slaves and were known as "comfort women. ${ }^{\text {xxvi }}$

During the Nanjing Atrocities ${ }^{\mathrm{xxxvii}}$ young and old women were repeatedly violated by Japanese Imperial troops. While definitive numbers are difficult to pin down because of the nature of the crime, tens of thousands of rapes were documented, witnessed, and reported. Philosophy professor Claudia Card expands upon the understanding of rape as a war crime by explaining the role rape holds in the crime of genocide. She explains: There is more than one way to commit genocide. One way is mass murder, killing individual members of a national, political, or cultural group. Another is to destroy a group's identity by decimating cultural and social bonds. Martial rape [rape committed during war] does both. . . If there is one set of fundamental functions of rape, civilian or martial, it is to display, communicate, and produce or maintain dominance. . . . Acts of forcible rape, like other instances of torture, communicate dominance by removing our control. She further continues by explaining that the violation involved in the crime of rape is intended to terrorize the victim and the nation being occupied, to destroy any community bonds that may exist, and to send a clear message of domination, humiliation, and power to both the victim and family members (particularly husbands, fathers, and sons, who may be unable to "protect" their wives, daughters, or children). Card states that rape can be used as a weapon of revenge and as a form of genetic or biologic imperialism. Professors John Roth and Carol Rittner expand upon this idea by explaining acts of rape resulting in unintentional pregnancy by the perpetrator group also can destroy a family's solidarity by "imposing" themselves into future generations. ${ }^{\mathrm{xl}}$ During WWI the German armies used rape as a part of the battle plan during the 
invasions of Belgium and of France. As constitutional law professor J.H. Morgan explains: "outrages upon the honour of women by German soldiers have been so frequent that it is impossible to escape the conviction that they have been condoned and indeed encouraged by German officers. ${ }^{\text {xli }}$ From the discussion so far we have understood that during war and armed conflict, rape is frequently used as a means of psychological warfare in order to humiliate the enemy. Kelly Dawn Askin observes that increasingly, the victims of war are civilians. An estimated forty-five million plus civilians died during World War II. Male and female civilians may be subject to torture, but many studies show that war rape is more frequently perpetrated on women than men. ${ }^{\text {xlii }}$ The incidents of wartime sexual violence occurred in a variety of situations, including institutionalized sexual slavery, wartime sexual violence associated with specific battles or massacres, and individual or isolated acts of sexual violence wherein the victims of war rape are usually "civilians", a category first recognized in the 19th century. Although war rape of women is documented throughout history, laws protecting civilians in armed conflict have tended not to recognize sexual assault on women. Even when laws of war have recognized and forbidden sexual assault, few prosecutions have been brought. According to Kelly Dawn Askin, the laws of war perpetuated the attitude that sexual assaults against women are less significant crimes, not worthy of prosecution. ${ }^{\text {xliv }}$ War rape has until recently been a hidden element of war, which according to Human Rights Watch is linked to the largely gender-specific character of war rape - abuse committed by men against women. This gender-specific character has contributed to war rape being "narrowly portrayed as sexual or personal in nature, a portrayal that depoliticizes sexual abuse in conflict and results in its being ignored as a war crime."xlv

RAPE AS A STRATEGIC WEAPON OF WAR- PSYCHO-SOCIOLOGICAL ANALYSIS OF MOTIVATING FACTORS RESPONSIBLE FOR RAPE IN WARFARE

"Rape used as a weapon of war demonstrates that women in one sense are objects of men's transactions in this context: they are not violated as individual women, but as the nation's women: the attack on their sexuality is an affront to the national collective of men."

\section{Kjersti Ericsson, Rape, Love and War - Personal or Political}

Sexual violence has been employed as a strategic weapon of war for at least as long as historians have been documenting conflicts. Indeed, members of nearly every standing army in history have participated in some form of rape warfare. ${ }^{x l v i}$ Consequently, the international community has implemented various forms of legislation to criminalize the deliberate targeting of civilians during armed conflict. Nonetheless, rape remains one of the most under-reported and inadequately prosecuted of all war crimes. History has shown, however, that the reality of wartime rape is unexpectedly complicated, and that the pervasiveness of sexual violence varies across and within conflicts. Various parties may use Sexual and Gender Based Violence (SGBV) differently in the same dispute, and the types and prevalence of SGBV may change both temporally and geographically. Rape has been highly violent and widespread in some conflicts, such as in Sierra Leone, Rwanda, and Democratic Republic of Congo, and rare in other conflicts, 
such as in Israel-Palestine and El Salvador. ${ }^{x \text { lix }}$ Certainly, a lack of discipline exhibited by inexperienced and non-professional warriors in conflicts can explain a fraction of these occurrences. Though, it would be disingenuous to affix such justifications upon those instances that are deliberately calculated by the professional soldiers and commanders of comparably advanced armies. ${ }^{1}$ Moreover, the sheer prevalence of its use precludes the validity of the "bad apple" argument, wherein a deviant minority becomes the scapegoat which suffers for the sins of an apathetic organization. ${ }^{l i}$ Indeed, sexual deprivation and base desire cannot explain why even educated military strategists would advocate the use of sexual violence in warfare however, it is necessary to understand that rape is neither incidental nor private. It routinely serves a strategic function in war and acts as an integral tool for achieving particular military objectives. Rape has been traditionally considered as a valuable weapon to strategically target the psychological wellbeing and social cohesion of civilian populations as well as the morale of enemy units. ${ }^{\text {lii }}$ Documenting where and how rape functions as a tool of military strategy is essential to counteract the longstanding view of rape in war as private or incidental. The attention to rape's strategic function, however, has attached much significance to "mass rape" and "rape as genocide." This emphasis on rape's scale as what makes it an abuse demanding redress distorts the nature of rape in war by failing to reflect both the experience of individual women and the various functions of wartime rape. Although rape is a sex-specific type of abuse, it generally functions like other forms of torture to intimidate and punish individual women. In some instances, however, it also can serve a strikingly sex-specific function, when, for example, it is committed with the intent of impregnating its victims. A Bosnian rape victim told Human Rights Watch, "It was their aim to make a baby. They wanted to humiliate us. They would say directly, looking into your eyes, that they wanted to make a baby. ${ }^{\text {liii }}$ This function of rape has never been reflected in the remedies available for rape victims. If anything, pregnancy is viewed as the "inevitable by-product of... rape," rather than as a distinct harm meriting its own remedy. ${ }^{\text {liv }}$ In some documented instances of rape, the abuse appears to serve not only strategic or political functions but also the perverse sexual gratification of the attacker. Somali women refugees in Kenya typically are raped after being successfully robbed. Rape in this context is thus not only a tool for frightening women into complying with their attackers' demands, but also inflicted specifically against them for sex. The plights of "young" and "pretty" Burmese women kidnapped by soldiers and kept at army barracks for raping is well documented. ${ }^{\text {lv }}$ Soldiers are motivated to rape precisely because rape serves the strategic interests delineated above. But the fact that it is predominantly men raping women reveals that rape in war, like all rape, reflects a gender-based motivation, namely, the assertion by men of their power over women. ${ }^{\text {lvi }}$ Soldiers can succeed in translating the attack upon an individual woman into an assault upon her community because of the emphasis placed—in every culture in the world—on women's sexual purity and the fact that societies define themselves, in overt or less clear-cut fashions, relative to their ability to protect and control that purity. It is the protection and control of women's purity that renders them perfect targets for abuse. In Turkey, an observer dismissed as impossible allegations of rape by Turkish government forces of Kurdish women-both civilians and guerrillas — on the basis that Turkish soldiers understand that virginity and women's honour are 


\section{Rape as a Continuing Weapon of Psychological Warfare, Suppression \& Subjugation}

sacred. Soldiers, it was argued, would not dare to defile women whose communities place a high social value on virginity and female modesty. ${ }^{\text {Ivii }}$ In fact, soldiers do rape women precisely because the violation of their "protected" status has the effect of shaming them and their communities. Seventeen-year old S., a Kurdish woman from southeastern Turkey, was detained by village guards and Anti-Terror police during a night raid on her village, accused of harbouring members of the Kurdish Workers' Party (PKK), raped during her interrogation, and taunted by her captors: "Now you're engaged, but after we rape you, no one will marry you." When she was released on a hillside in the middle of the night, S.'s captors warned her not to speak of the rape, "because it would be very bad for" her. S.'s story suggests that rapists may also be motivated by the likelihood that their victims will not report the assault. By virtue of being a rape victim, a woman becomes the perceived agent of her community's shame. In a bizarre twist, she changes from a victim into a guilty party, responsible for bringing dishonor upon her family or community. As a result, women victims, whether for fear of being seen this way, or because they see themselves this way, are extremely reluctant to report rape. The shame of rape may keep women, who would rather bury their "dishonor," from seeking punishment for their attackers. K.S., a fifty-four-year-old housewife who was raped in her home by Serbian soldiers, told Human Rights Watch, "What happened to me, happened to many, but the women keep it secret. It is shameful. Thus the mother conceals it if it happened to her daughter so she can marry and if it happened to an older woman, she wants to protect her marriage. ${ }^{\text {lix }}$ In Burma, government soldiers rape Rohingya women, thus identifying their victims by their sex and their ethnic affiliation. Rape by the security forces in Peru is strongly determined by race and class: rape victims are overwhelmingly poor and brown-skinned. And Somali women refugees report that they are asked by their rapists to which clan they belong. Women who are the same clan as their attackers may still be robbed, but often are spared rape. ${ }^{\mathrm{lx}}$ The UN Security Council Resolution 1820 of 2008 made the crucial step of identifying rape as a specific tactic of war. It was vital to officially acknowledge that the use of sexualized violence by armed forces and military groups may be strategically adopted as a means of infiltrating populations, destroying communities, demoralizing civilians and leaving a devastating lasting legacy.

Women under Siege have identified 10 separate reasons why rape is used as a tool of the Democratic Republic of Congo's war. The case study of DRC's War helps us to penetrate inside the mind of perpetrators of Rape in Armed Conflict. The reasons of Sexual violence including rape given by victims are more or less similar in every Armed Conflict (Military or Civil) wherein 'Rape' was extensively used as a war-weapon. The reasons of sexual violence, including rape given by Congolese rape-victims are as follows: ${ }^{. x i}$

To humiliate: Researchers Maria Eriksson Baaz and Maria Stern write that "while sexual and other violence is often used to humiliate and intimidate, this humiliation and intimidation is much less strategic and much more complex than a combat strategy to further military/political gains." (The two interviewed soldiers for a 2010 working paper published by the Nordic Africa Institute called "The Complexity of Violence.") ${ }^{\text {xii }}$ 
To “protect” soldiers: Lisa Jackson’s 2008 documentary, “The Greatest Silence,” shows Mai Mai militia members talking about why they rape. One of them discusses how fighters rely on the "magic power" of raping a woman. Some fighters believe it fortifies them for battle. "Well, we were just abiding by the conditions of our magic potion," said one. "We had to rape women in order to make it work, and beat the enemy.”

To terminate pregnancies: Some evidence points to perpetrators targeting pregnant women. One survivor interviewed by the BBC recounts that her rapists purposely aborted her ninemonth-old fetus with objects after raping her. Other women report miscarriages following their attacks.

To control communities, territory, or natural resources: Chloe Christman of the Enough Project's Raise Hope for Congo Campaign confirms that in a country rife with conflict over mineral wealth, rape is often targeted at women in communities in close proximity to mines and other resources. However, soldiers are so strategic about deciding whom to attack that they purposely avoid raping women in certain communities if they think that earning the group's trust through less violence will ensure greater access to that area's resources. Christman says armed groups are "very smart and can be very calculating" when deciding whether or not to attack, and whom. Their thinking seems to be, "Am I going to get more by raping these women or by providing the thought of protection to this community?"lxiii

To increase food insecurity: Women are targeted especially near camps for internally displaced persons (IDPs) while they search for firewood or try to cultivate crops, says Christman. While there is the possibility that militia members are raping women who happen to be out doing these tasks, experts say that rape has repeatedly been used to procure a community's resources in DRC, and that militia groups are strategically targeting these women.

To silence: A report from United States Institute of Peace in conjunction with the Harvard Humanitarian Initiative indicates that the Lord's Resistance Army (LRA), a militant group that operates from Uganda to South Sudan to DRC, mutilates and sometimes kills civilians "to deter communities from disclosing LRA whereabouts.",xiv

“The devil made me do it”: Some Mai Mai soldiers tell interviewers that Satan provokes them to rape. Others more generally speak of acting on a sudden desire when they see a woman, and of the anonymity that allows them to commit acts they would otherwise avoid in their civilian lives. In a separate study of rape among combatants in the state's Armed Forces of the Republic (FARDC), a team of Swedish researchers found that FARDC soldiers also differentiated between "normal" rape-to fulfil sexual "needs"-and "bad" or "evil” rape, which might entail mutilations or the abuse of children. 
To avoid violence from superiors: Mai Mai militia men tell researchers that they rape even when they don't want to. The consequences of not committing sexualized violence, they say, would be a severe beating by their superiors.

To express frustration or anger: The Swedish researchers found that FARDC soldiers used sexualized violence as a way to alleviate or express their anger at being hungry, impoverished, or "unloved" by their wives. One soldier speaks of his suffering and how anger over the lack of resources in his life takes on the form of rape, murder, and looting. "You feel you have to do something bad," he says. "You mix it all: sabotage, women, stealing, rip the clothes off, killing." At least two soldiers Jackson interviews state matter-of-factly that one of the reasons rape occurs is that soldiers spend "too long" in the bush without women. Therefore, according to their logic, when they do encounter a woman, they will necessarily rape her. They use this reasoning with respect to their own personal abuse of women as well as when they describe rape committed by Hutu soldiers.

To retaliate: Women whose husbands are important figureheads in a community or support a different militia than the one invading at a given time are often raped in retaliation.

The statistics given below ${ }^{\mathrm{lxv}}$ is self-explanatory about the role that RAPE has played in War. As the reporting of rape has improved, the scale of the crime has become more horrifyingly apparent. The Statistics is just not about numbers, but it is more about the revelation of demonic side of mankind that comes up from to time during armed conflicts.

\begin{tabular}{|l|l|}
\hline \multicolumn{2}{|c|}{ CUSTOMARY EVIL } \\
\hline \multicolumn{2}{|c|}{ RAPE DURING CONFLICTS- THE STATISTICS } \\
\hline $\begin{array}{l}\text { CONFLICT } \\
\text { War, Nanking 1937 Army in }\end{array}$ & $\begin{array}{l}\text { ESTIMATED RAPES } \\
\text { Army during World War II) }\end{array}$ \\
\hline $\begin{array}{l}\text { Soviet } \\
\text { Germany, World War II }\end{array}$ \\
\hline $\begin{array}{l}\text { Pakistani Army during } \\
\text { the Bangladesh War of } \\
\text { Secession, 1971 }\end{array}$ & 200,000 \\
\hline $\begin{array}{l}\text { Bosnian War, 1992- } \\
\text { 1995 }\end{array}$ & 20,000 \\
\hline $\begin{array}{l}\text { Sierra Leone Civillion War, } \\
1991-2002\end{array}$ & Over 50,000 then were provided to Japanese \\
\hline $\begin{array}{l}\text { Rawandan Genocide, } \\
\text { 1994 500,000 }\end{array}$ & \\
\hline
\end{tabular}

Source-The Economist 
ANALYSIS OF EFFECTS OF GENDER BASED SEXUAL VIOLENCE (including Rape) IN CONFLICT AND POST-CONFLICT WAR ZONES

"Traumatized people suffer damage to the basic structures of the self. They lose trust in themselves, in other people; in God...The identity they have formed prior to the trauma is irrevocably destroyed."

Judith Lewis Herman, Trauma and Recovery, 1992

The effects of Gender-based violence can be devastating and long lasting. They pose danger to a woman's reproductive health and can scar a survivor psychologically, cognitively and interpersonally. Increased levels of sexual and gender-based violence can often persist well after the end of a crisis. Women and girls are usually disproportionally affected, and crimes such as these have devastating, long-term effects on the lives of survivors, their families, and the communities in which they live. The following are some of the effects of Sexual violence in Armed Conflict on women:

1. Sexually transmitted diseases are lasting consequences of sexual violence and are major a major health concern for women in conflict zones.

2. Physical harms such as injury to reproductive organs, traumatic fistulas, and infertility often accompany brutal or repeated rapes. Attempts at abortion following an unwanted pregnancy from rape may also have severe medical complications, and women who are pregnant at the time of the attack frequently miscarry

3. Serious psychological disorders including depression, anxiety, post-traumatic stress disorder, shock, memory loss, and sexual dysfunction.

4. Rape trauma syndrome, a syndrome used to describe emotional responses to sexual assault including hopelessness, loss of control, anger, guilt, and phobias.

5. Suicide, behaviour disorders, and eating disorders.

6. Fear of additional sexual violence may also keep women from going about their normal activities, such as attending school, engaging in the market, or participating in politics

7. Reintegration difficulties and social stigma

8. Another consequence facing victims of Gender based sex violence in conflict areas involves the process of justice and reparations. Sex violence including Rape is sometimes viewed primarily as a violation of the male's (husband, father, etc.) property rights, not as a violation of the woman's human rights. This perspective can have a substantial impact on the justice and reparations process. ${ }^{\text {lxvi }}$

9. Families who have lost a female member of their household, therefore, often receive grossly inadequate compensation for their loss. For example, in Northern Ireland the reparations made by the government for the military-caused conflict death of a mother of six children totalled $£ 84$.

The anarchy and impunity of war goes some way to explaining the violence. The conditions of war are often conducive to rape. Young, ill-trained men, fighting far from home, are freed from 
social and religious constraints. The costs of rape are lower, the potential rewards higher. And for ill-fed, underpaid combatants, rape can be a kind of payment. Considering the type of wars fought today. Many recent conflicts have involved not organised armies but scrappy militias fighting amid civilians. As wars have moved from battlefields to villages, women and girls have become more vulnerable. For many, the home front no longer exists; every house is now on the front line, and at the end, the sex violence perpetrated against woman not only destroy her, but destroy the community and culture she belongs to. ${ }^{\text {lxviii }}$

\section{CONCLUSION}

When war crimes are committed against women and children in similar ways as they are to men, they are universally recognized as atrocities and have been punished as such . . A problem arises however when war crimes and genocidal atrocities are committed against women and girls in gender-specific ways. Hundreds of thousands of women, this century alone, have been raped in wars . . . The 'universal soldier' it seems, always has, and to this day, does, rape with impunity. ${ }^{\text {lxix }}$ The degradation of women has always been the focal point of Battle. History shows that Mass rape was used not only as an instrument of terror and humiliation but also a tool to achieve political goals. There is a common belief about chastity and purity of woman shared by almost all the cultures and religions. Thus, many of the victims of rape in Armed conflicts experienced not only the usual consequences associated with such trauma, but also rejection and ostracism from their own communities. Several were denied marriage or the opportunity to have children. The final dimension associated with the Armed conflicts involved a program of ethnic cleansing. As is the case in Rwanda, East Pakistan (Now Bangladesh), Bosnia-Herzegovina by fathering children. These perpetrators believed that they could nullify every aspect of the mother's identity, including her ethnic and religious identity, by raping and impregnating her. Rape and sexual atrocity "work" as tactics to destroy another group for many reasons like physical death, submission and terror, humiliation, ethnic cleansing, self hatred, community breakdown, a belief that rape 'dilutes' the race of the next generation etc. Considering the ambit of problem, its international nature and its collective impact on the world at large, Humanitarian organizations need to design common protocols that take into account the medical, psychological and social impact of all types of sexual violence in Warzones. War-time rapes left deep and lasting consequences on the mental health of the victims and their families. Thus, survivors require treatment to improve their own individual lives, but repairing survivors also empowers them to revive their communities, and non-individualistic, community-level treatments remain essential as well. It is an undeniable fact that sexualized violence is political which further acknowledges the fact that sexualized violence does not need to happen which simply means that it is not an inevitable byproduct of war hence, can be stopped. However, we have collectively failed to act to halt the genocide in World Wars, Rwanda, East Pakistan, Bangladesh, BosniaHarzegovina, Congo, Uganda and Sudan. And Yet we continue to say, “Never again”... The time has come to become more civilized in the interest of future generations, in the interest of existence of human race. 


\section{RECOMMENDATIONS}

Every year, tens of thousands of men, women, and children endure sexual violence during and after armed conflict. According to international law, using rape as a weapon of war is a war crime. Despite this legal protection, armies in dozens of global conflicts have used rape as a tactic of war with impunity. Considering the global aspect of 'Wartime Rape Epidemic' Author recommends,

1. That, ending impunity must be at the core of any systematic response to the crisis of sexual violence. The rate of prosecutions should increase.

2. That, the steps should be taken to improve the accountability of crimes of wartime sexual violence.

3. That, the Armies that Rape should be publicly named and shamed. Soldier or commander whoever engage in any sexual violence including Rape or tolerate it must be identified and shame publicly.

4. That, Countries should make aid and weapon transfers to armed groups conditional on their human rights record and swiftly withdraw both if soldiers are reported to rape civilians.

5. That, the political leaders, representatives of nation/groups and its Armed Forces that order or tolerate Rape should be severely punished by imposing sanctions like travel banns etc.

6. That, the tasks of investigating, prosecuting and judging crimes of rape need special attention. Personnel working in these areas need to take special care not to cause even more trauma for victims of sexual assault.

7. That, wishes, rights, and the dignity of the victim shall be respected when taking action to prevent or respond to an incident of sexual violence

8. That, procedures that grant State officials immunity from prosecution in cases of serious human rights violations, such as rape be removed.

9. That, police, prosecutors, judicial authorities and medical staff in the treatment of victims of sexual violence, and in the conduct of criminal investigations and the collection of forensic evidence be properly trained.

10. That, a safe and supportive environment for victims to seek and receive medical and legal services be created. Personal psychologist must be appointed to tackle the shattered mind and emotional damage-the post traumatic stress disorder of War Rape victim.

11. That, Medical personnel working in conflict settings must be trained to recognize victims of rape and to address both the immediate and long-term consequences. Psychological interventions are complicated by the reality that rape in wartime usually happens against a backdrop of other traumas and losses. In this context, mental health programs for rape victims must be broad based and target a variety of traumas.

12. That, whether the punishment of perpetrators and compensation for victims are in accordance with the gravity of the crime and international human rights standards, particularly those on cruel, inhuman or degrading treatment or punishment shall be ensured. 


\section{REFERENCES \& CITATIONS}

${ }^{\mathrm{i}}$ Pyke, Michael; Rose, Gillian; Whatmore, Sarah (2003), Using Social Theory-Thinking through Research, SAGE Publications. P 50.

ii Merry, Sally Engle (2009), Gender Violence A Cultural Perspective, Wiley-Blackwell. P. 03 iiiRape is a type of sexual assault usually involving sexual intercourse or other forms of sexual penetration perpetrated against a person without that person's consent. The act may be carried out by physical force, coercion, abuse of authority or against a person who is incapable of giving valid consent, such as one who is unconscious, incapacitated, has a intellectual disability or below the legal age of consent.

iv Corinne J. Saunders, Rape and Ravishment in the Literature of Medieval England, Boydell \& Brewer, 2001, p. 20.

v "Rape". Merriam-Webster

vi Keith Burgess-Jackson, A Most Detestable Crime: New Philosophical Essays on Rape, Oxford University Press, New York, 1999, p.16.

vii Corinne J. Saunders, Rape and Ravishment in the Literature of Medieval England, Boydell \& Brewer, 2001, p. 20.

viii Clark M. Congo: confronting rape as a weapon of war. The Christian Science Monitor 2009 Aug 4.

ix Gettleman J. Rape epidemic raises trauma of Congo war. The New York Times 2007 Oct 7

x http://www.forbes.com/sites/worldviews/2013/01/02/rape-every-20-minutes-for-the-worldslargest-democracy/\#44a1f7116da5, Accessed on $12^{\text {th }}$ May, 2015

xi 2 CBC News, Apr 30, 2013: < http://www.cbc.ca/news/world/story/2013/04/30/india-rapevictim-dies.html $>$, Accessed on $10^{\text {th }}$ June, 2015

xii National Crimes Record Bureau, Crime in India 2012 - Statistics Government of India (May 2013)

xiii Vasundhara Sirnate (1 February 2014). "Good laws, bad implementation". Chennai, India: The Hindu. Retrieved 1 February 2014.

xiv "Rape statistics around the world". Indiatribune.com. 2012-09-11. Retrieved 2013-03-17.

xv Schmalleger, John Humphrey, Frank (2011). Deviant behavior (2nd ed.). Sudbury, MA: Jones \& Bartlett Learning. p. 252. ISBN 0763797731.

xviS. Harrendorf, M. Heiskanen, S. Malby,INTERNATIONAL STATISTICS on CRIME AND JUSTICE United Nations Office on Drugs \& Crime (2010)

xvii

http://idsn.org/wpcontent/uploads/user_folder/pdf/New_files/Key_Issues/Dalit_Women/G0913456.pdf, Accessed on $10^{\text {th }}$ June, 2015

xviiihttp://www.rightlivelihood.org/fileadmin/Files/PDF/Literature_Recipients/Manorama/Backg round_Manorama.pdf, Accessed on $12^{\text {th }}$ June, 2015

xix Chatterji, Angana P. (2012). Ania Loomba, Ritty A. Lukose, ed. South Asian Feminisms. Duke University Press. p. 194. ISBN 978-0822351795. 
xx Amnesty International, India: Torture, Rape and Deaths in Custody, (London: March, 1992), p. 21.

xxi Wilhelm von Pochhammer (1981). India's road to nationhood: a political history of the subcontinent. Allied Publishers. pp. 512-. ISBN 978-81-7764-715-0.

xxii http://datab.us/i/Rape\%20during\%20the\%20Bangladesh\%20Liberation\%20War，Accessed on $15^{\text {th }}$ June, 20154

xxiii Brownmiller, Susan; “Against our will: Men, Women and Rape”, Published by “Open Road Integrated Media”, New York,

xxiv Manoj Joshi (January 1999). The lost rebellion. Penguin Books. p. 64. ISBN 978-0-14027846-0.

xxv Warikoo, Kulbhushan (2010). Kulbhushan Warikoo, ed. Religion and security in South and Central Asia(1st ed.). Routledge. p. 79. ISBN 978-0415575904.

xxvi Forsythe, David P. (2009). Encyclopedia of Human Rights. Oxford University Press. p. 306. ISBN 978-0195334029.

xxvii Karlsson, B. G. (2011). Unruly Hills: A Political Ecology of India's Northeast. Berghahn. p. 51.ISBN 978-0857451040.

xxviii Bhowmick, Nilanjana (31 August 2012). "Gujarat Riots: New Court Verdict Raises the Heat on Narendra Modi". Time. Retrieved 6 May 2014.

xxix Vasundhara Sirnate (1 February 2014). "Good laws, bad implementation". Chennai, India: The Hindu.

xxx Homer, The Iliad (New York: Viking Penguin, 1990) p 81.

xxxi Dianna Marder, Once Again, Rape Becomes a Weapon of War, Atlanta Journal and Constitution, February 17, 1993 at p1

xxxii Declaration on the Elimination of Violence Against Women, G.A. Res. 48/104, art. 1, U.N. Doc. A/48/49 (Dec. 20, 1993).

xxxiii Ibid. Art. 2

xxxiv Mobilizing the Will to Prosecute: Crimes of Rape at the Yugoslav and Rwandan Tribunal xxxv Trial of the Major War Criminals Before the International Tribunal 456 (1947).

xxxvi Danise Aydelott, Mass Rape During War: Prosecuting Bosnian Rapists Under International Law, Emory International Law Review

xxxvii http://www.nanking-massacre.com, Accessed on $17^{\text {th }}$ August, 2015

xxxviii http://www.historyplace.com/worldhistory/genocide/nanking.htm, Accessed on $17^{\text {th }}$ August, 2015

xxxix Claudia Card, "Rape as a Weapon of War," Hypatia 11, no. 4: Women and Violence (Autumn 1996): 7.

xl Facing History and Ourselves video with Profesors John Roth and Carol Rittner. xli Brownmiller, Susan; “ Against Our Will: Men, Women and Rape”, 38 (1975) p 42.

xlii Thomas, Dorothy Q.; Reagan, E. Ralph (1994)."Rape in War: Challenging the Tradition of Impunity". SAIS Review, Johns Hopkins University Press. Archived from the original on 2008-03-06. 
xliii Askin, Kelly Dawn (1997). War Crimes Against Women: Prosecution in International War Crimes Tribunals. Martinus Nijhoff Publishers. ISBN 90-411-0486-0.

xliv Ibid, p13

xlv Thomas, Dorothy Q.; Reagan, E. Ralph (1994). "Rape in War: Challenging the Tradition of Impunity". SAIS Review, Johns Hopkins University Press. Archived from the original on 2008-03-06.

xlvi Vikman, E. (2005). Ancient origins: Sexual violence in warfare, part I. Anthropology \& Medicine, 12(1), 21-31. doi:10.1080/13648470500049826

xlvii Bergoffen, D. B. (2006). From genocide to justice: Women's bodies as a legal writing pad. Feminist Studies, 32(1), 11-37, 192.

xlviii Falcon, S. (2001). Rape as a weapon of war: Advancing human rights for women at the U.S.-Mexico border. Social Justice, 28(2), 31-50.

xlix E.J. Wood, “Armed Groups and Sexual Violence: When Is Wartime Rape Rare?” Politics and Society, vol. 37, no. 1 (2009): 131-61

IValenius, J. (2004). Living in an over-organized jungle: Military discipline, masculinity and rape in Casualties of War. Paper presented at the Annual Meeting of the International Studies Association. Montreal, Canada.

li Whitmer, B. (2006). “Torture chambers and rape rooms”: What Abu Ghraib can tell us about the American carceral system. CR: The New Centennial Review, 6(1), 171-194, 285.

lii Clifford, C. (2008). Rape as a weapon of war and its long-term effects on victims and society. Paper presented at the 7th Global Conference: Violence and the Contexts of Hostility. Budapest, Hungary.

liii Helsinki Watch, War Crimes in Bosnia-Hercegovina, 215.

liv Anne Tierney Goldstein, Recognizing Forced Impregnation as a War Crime Under

lv UN. Commission on Human Rights, Report on the Situation of Human Rights in Myanmar, 49th Sess., at 16, E/CN.4/1993/37 (February 17, 1993).

lvi U.N. Division for the Advancement of Women, Report of the Expert Group Meeting on Measures to Eradicate Violence Against Women (New York; October 8,1993).

lvii Interview by Human Rights Watch, Istanbul, Turkey, July 1993.

lviii Interview by Human Rights Watch, Diynrbakir, Turkey, July 15, 1993.

lix Helsinki Watch, War Crimes in Bosnia-Hercegovina, 170.

lx Women's Rights Project/Africa Watch, Seeking Refuge, 7.

lxi http://www.womenundersiegeproject.org/conflicts/profile/democratic-republic-ofcongo\#reasons, Accessed on $20^{\text {th }}$ September, 2015

lxii Eriksson-Baaz, M., \& Stern, M. (2010). The Complexity of Violence: A critical analysis of sexual violence in the Democratic Republic of Congo (DRC). Sida Working Paper on Gender-based Violence.

lxiii http://www.enoughproject.org/blogs/chloe-christman, Accessed on $23^{\text {rd }}$ September, 2015

lxiv http://www.usip.org/category/countries/democratic-republic-of-the-congo, Accessed on $26^{\text {th }}$ September, 2015 
lxv http://www.economist.com/node/17900482, Accessed on 29 $9^{\text {th }}$ September, 2015

lxvi Gender Research And Advocacy Project, Legal Assistance Center, Withdrawn: Why Complainants withdraw Rape Cases In Namibia, p 2- 3 (2009).

lxviiThe Pat Finucane Centre For Human Rights and Social Change, Kathleen Thompson Family Win Judicial Review/Judge Slams Murder Investigation, http://www.patfinucanecentre.org, Accessed on, $2^{\text {nd }}$ October 2015

lxviii https://katieandjamie.wordpress.com/2011/03/17/the-rape-of-congos-greatest-resource/, Accessed on $2^{\text {nd }}$ October, 2015

lxix Ariane Brunet \& Stephanie Rousseau, Acknowledging Violations, Struggling against Impunity: Women’s Rights, Human Rights, in Common Grounds, p 33. 